Yale Agrarian Studies Series

James C. Scott, series editor 
The Agrarian Studies Series at Yale University Press seeks to publish outstanding and original interdisciplinary work on agriculture and rural society - for any period, in any location. Works of daring that question existing paradigms and fill abstract categories with the lived-experience of rural people are especially encouraged.

- James C. Scott, Series Editor 


\section{The Art of}

Not Being Governed

An Anarchist History of Upland Southeast Asia

James C. Scott

Yale University Press NEW Haven \& LONDON 
Published with assistance from the Mary Cady Tew Memorial Fund.

Copyright (C) 2009 by Yale University.

All rights reserved.

This book may not be reproduced, in whole or in part, including illustrations, in any form (beyond that copying permitted by Sections 107 and 108 of the U.S. Copyright Law and except by reviewers for the public press), without written permission from the publishers.

Designed by James J. Johnson and set in Ehrhardt type by Tseng Information Systems, Inc. Printed in the United States of America.

\section{Library of Congress Cataloging-in-Publication Data}

Scott, James C.

The art of not being governed : an anarchist history of upland Southeast Asia / James C. Scott. p. $\mathrm{cm}$.

Includes bibliographical references and index.

ISBN 978-0-300-I 5228-9 (cloth : alk. paper) I. Ethnology-Southeast Asia. 2. PeasantrySoutheast Asia-Political activity. 3. Southeast Asia-Politics and government-I945-. 4. Southeast Asia-Rural conditions. I. Title.

DS523.3.S36 2009

$305.800959-\mathrm{dc2} 2$

A catalogue record for this book is available from the British Library.

This paper meets the requirements of ANSI/NISO Z39.48-I992 (Permanence of Paper).

Iо $\quad 9 \begin{array}{lllllllll} & 8 & 7 & 6 & 5 & 4 & 3 & 2 & \text { I }\end{array}$ 
It is said that the history of peoples who have a history is the history of class struggle. It might be said with at least as much truthfulness, that the history of peoples without history is a history of their struggle against the state.

-Pierre Clastres, La société contre l'état 
This page intentionally left blank 